\title{
Analisis Spasial berdasarkan Indeks Getis Ord Data Laju Inflasi Tahunan di Pulau Sumatra
}

\author{
http://dx.doi.org/10.28932/jutisi.v6i1.2317
}

\author{
Yuni Naomi Yenusi ${ }^{\bowtie \# 1}$, Adi Setiawan ${ }^{* 2}$, Lilik Linawati ${ }^{\# 3}$ \\ \# Jurusan Matematika, Universitas Kristen Satya Wacana \\ Jl. Diponegoro 52-60 Salatiga \\ 1662016011@student.uksw.edu \\ ${ }^{3}$ lilik. linawati@staff.uksw.edu \\ * Jurusan Matematika, Universitas Kristen Satya Wacana \\ Jl. Diponegoro 52-60 Salatiga \\ 2adi.setiawanestaff.uksw.edu
}

\begin{abstract}
This study discusses an analysis of year-on-year inflation data on the island of Sumatra using Getis-Ord General $G$ index and Getis-Ord Gi* Index, which will be compared with Bootstrap Method and Mann Withney Test for comparison of two time periods. The results showed that the highest average inflation was in Pangkal Pinang City by 5.82, and the lowest was in Banda Aceh City by 3.63. There is a significant difference in the median inflation rate from the cities of inflation on the island of Sumatra except in the cities of Banda Aceh, Palembang and Batam. With a significance level $\alpha=5 \%$, it is concluded that there are spatial cluster and spatial autocorrelation patterns in February 2014. City with high inflation value cluster with its neighbors is the city of Pangkal Pinang, and the low inflation value cluster is Banda Aceh. It means that a region is close to other regions has a similar level of inflation in terms of high and low at a certain time. In other words, commodities contributing to inflation between adjacent regions are interrelated.
\end{abstract}

Keywords- Getis-Ord General G Index; Getis-Ord Gi* Indeks; Inflation; Spatial Autocorrelation; Spatial cluster.

\section{Pendahuluan}

Bank Indonesia mendefinisikan inflasi sebagai suatu kecenderungan meningkatnya harga-harga barang dan jasa secara umum dan terus menerus. Kebalikan dari inflasi disebut deflasi yaitu penurunan harga-harga barang dan jasa secara umum dan terus menerus [1]. Inflasi terjadi karena keterbatasan komoditas yang beredar dan mengakibatkan ditahannya barang dan jasa yang ditawarkan oleh para pengusaha, sehingga konsumen akan memperoleh barang dan jasa tersebut dengan harga yang tinggi [2].

Pulau Sumatra merupakan pulau kedua terbesar yang memberikan kontribusi terhadap pertumbuhan ekonomi di Indonesia jika dilihat dari struktur ekonomi Indonesia secara spasial, misalnya kontribusi yang diberikan Pulau Sumatra pada tahun 2018 adalah sebesar 21,58\% [3]. Inflasi kotakota di Pulau Sumatra bergerak fluktuatif seperti tekanan inflasi Sumatra pada triwulan IV tahun 2018 lebih rendah dari triwulan III tahun 2018, hal ini disebabkan oleh rendahnya tekanan inflasi bahan pangan yang dipengaruhi oleh beberapa komoditas seperti cabai merah dan cabai rawit yang mengalami deflasi tahun ke tahun masingmasing sebesar $26,3 \%$ dan $21,9 \%$ [3].

Perbandingan antar periode waktu perlu dilakukan seperti pada perbandingan data inflasi karena inflasi dari tahun ke tahun terus berubah mengikuti perkembangan ekonomi di suatu daerah seperti pada penelitian yang dilakukan oleh Setiawan [4] yang berjudul "Perbandingan Karakteristik Inflasi kota-kota di Indonesia bagian Timur Sebelum dan sesudah Krisis Moneter 1998". Hasil penelitian menunjukkan bahwa inflasi tahunan untuk kota-kota tersebut cenderung memiliki pola yang sama setelah krisis moneter namum sebelum krisis moneter terjadi ada satu kota yang memiliki pola yang cenderung berbeda dengan kota-kota lain yaitu kota Ambon. Hal yang sama dianggap perlu untuk dilakukan untuk melihat karaktersitik dari inflasi di Pulau Sumatra.

Daerah yang berdekatan cenderung memiliki kesamaan karakteristik sehingga perlu dilihat apakah daerah yang saling berdekatan memiliki keterkaitan secara spasial, seperti penelitian yang dilakukan oleh Nisa [5] di kota-kota di Provinsi Papua Barat untuk mengetahui adanya pengaruh spasial pada kondisi pembangunan manusia lebih tepatnya mengindentifikasi adanya dependensi IPM (Indeks Pembangunan Manusia) antar kota di Provinsi Papua Barat dan dari hasil penelitian menunjukkan kota di Provinsi Papua Barat tidak terdapat dependensi spasial terhadap angka IPM pada tahun 2012. Penelitian yang serupa juga 
dilakukan oleh Wuryandari [6] yang mengidentifikasi jumlah pengangguran di Jawa Tengah menggunakan Indek Moran untuk menentukan hubungan antar daerah terkait jumlah penganggurannya dan hasil penelitian menunjukkan adanya autokorelasi spasial yang positif. Penelitian yang dilakukan oleh Nisa menggunakan pengujian dengan Indeks Moran, begitu pula penelitan yang dilakukan oleh Wuryandari sedangkan dalam penelitian ini akan digunakan Pengujian dengan Indeks Getis-Ord.

Oleh karena itu diperlukan metode statistik deskriptif untuk melihat karakteristik laju inflasi di Pulau Sumatra, Uji Mann Whitney untuk perbandingan laju inflasi periode lima tahun pertama dan lima tahun berikutnya dan Getis-Ord General $\mathrm{G}$ dan Getis-Ord Gi* untuk melihat keterkaitan antar satu daerah dengan daerah lainnya dan untuk meyakinkan hasil yang diperoleh maka dengan metode Bootstrap akan dilakukan resampling pada data dan kemudian dilakukan uji.

\section{DASAR TEORI}

\section{A. Inflasi}

Bank Indonesia awalnya mengartikan inflasi sebagai kenaikan uang beredar atau kenaikan likuditas dalam suatu perekonomian. Dalam perkembangannya lebih lanjut inflasi diartikan sebagai suatu kecenderungan meningkatnya hargaharga barang dan jasa secara umum dan terus menerus. Kebalikan dari inflasi disebut deflasi. Penentuan tingkat inflasi dapat dilakukan dengan terlebih dahulu menentukan indeks harga, perhitungan inflasi biasanya menggunakan indikator Indeks Harga Konsumen (IHK) yaitu indeks harga dari harga barang-barang yang selalu digunakan para konsumen dimana perubahan IHK dari waktu ke waktu menunjukkan harga dari paket barang dan jasa yang dikonsumsi masyarakat. Inflasi yang diukur dengan IHK di Indonesia dikelompokan dalam 7 kelompok pengeluaran yaitu Kelompok Bahan makanan, kelompok makanan jadi, rokok dan tembakau, kelompok perumahan, air, listrik, gas, dan bahan bakar, kelompok sandang, kelompok kesehatan, kelompok pendidikan, rekreasi dan olahraga, dan kelompok transport,komunikasi dan jasa keuangan [1]. Laju Inflasi dan IHK dirumuskan seperti pada persamaan (1) dan (2) berikut ini [2].

$$
\begin{aligned}
& \text { Laju inflasi }=\frac{I H K_{t}-I H K_{(t-1)}}{I H K_{(t-1)}} \times 100 \\
& I H K=\frac{P_{t}}{P_{(t-1)}}
\end{aligned}
$$

\section{B. Uji Mann-Whitney}

Mann-Whitney merupakan alat uji statistik untuk menguji hipotesis median dua sampel saling bebas [7]. Adapun langkah-langkah dalam Uji Mann-Whitney adalah sebagai berikut:

1. Menentukan hipotesis $\left(\mathrm{H}_{0}\right.$ dan $\left.\mathrm{H}_{1}\right)$.

$\mathrm{H}_{0}$ : Tidak terdapat perbedaan median data pada dua periode waktu yang dibandingkan
$\mathrm{H}_{1}$ : Terdapat perbedaan median data pada dua periode waktu yang dibandingkan

2. Menentukan taraf signifikansi $\alpha$.

3. Menentukan nilai uji statistik ( $\mathrm{U}_{\text {hitung }}$ ) menggunakan rumas pada persamaan (3) dan (4).

$$
\begin{aligned}
& U_{1}=n_{1} n_{2}+\frac{1}{2} n_{1}\left(n_{1}+1\right)-R_{1} \\
& U_{2}=n_{1} n_{2}+\frac{1}{2} n_{2}\left(n_{2}+1\right)-R_{2} \\
& \text { dengan : } \\
& \mathrm{n}_{1} \text { : ukuran sampel kelompok } 1, \\
& \mathrm{n}_{2} \text { : ukuran sampel kelompok } 2, \\
& \mathrm{R}_{1} \text { : jumlah rangking kelompok } 1, \\
& \mathrm{R}_{2} \text { : jumlah rangking kelompok } 2, \\
& \text { Nilai } U \text { terkecil diambil sebagai } U_{\text {hitung }}
\end{aligned}
$$

4. Mengambil kesimpulan jika $U_{\text {hitung }}<U_{\text {Tabel }}$ maka $H_{0}$ ditolak.

\section{Analisis Data Spasial}

Benerjee dalam Yuriantari menjelaskan bahwa data yang memuat informasi "lokasi", jadi tidak hanya "apa" yang diukur tetapi menunjukkan lokasi dimana data itu berada disebut data spasial [8]. Analisis spasial membutuhkan suatu data yang berdasarkan lokasi dan memuat karakteristik dari lokasi tersebut. Lokasi pada data spasial harus diukur agar dapat diketahui adanya efek spasial yang terjadi.

Ada 2 sumber informasi lokasi yang dapat diketahui menurut Kosfeld dalam Wuryandari [6] yaitu :

1. Hubungan ketetanggaan (neighborhood), hubungan ketetanggaan mencerminkan lokasi relatif dari satu unit spasial atau lokasi ke lokasi yang lain dalam ruang tertentu.

2. Jarak (distance), lokasi yang terletak dalam suatu ruang tertentu dengan adanya garis lintang dan garis bujur menjadi sebuah sumber informasi.

\section{Matriks Bobot Spasial}

Membangun matriks bobot objek spasial merupakan hal penting dalam analisis spasial. Perlu dilakukan perhitungan matriks kedekatan spasial (spatial contiguity matrix) sebelum membentuk matriks bobot objek. Matrik contiguity memiliki grid umum kedekatan/ketetanggaan yang dapat didefinisikan dalam beberapa cara :

1. Rook Contiguity (berdasarkan gerak catur) : Wilayah pengamatan bersentuhan langsung dengan sisi-sisi wilayah tetangga sehingga akan memiliki 4 tetangga. Ketetanggaan Rook Contiguity dapat dilihat pada Gambar 1. 


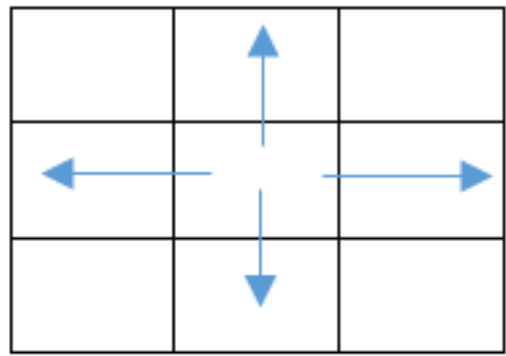

Gambar 1. Rook Contiguity

2. Bishop Contiguity: Wilayah pengamatan bersentuhan langsung dengan sudut diagonal wilayah tetangga sehingga akan memiliki 4 tetangga. Ketetanggaan Bishop Contiguity dapat dilihat pada Gambar 2.

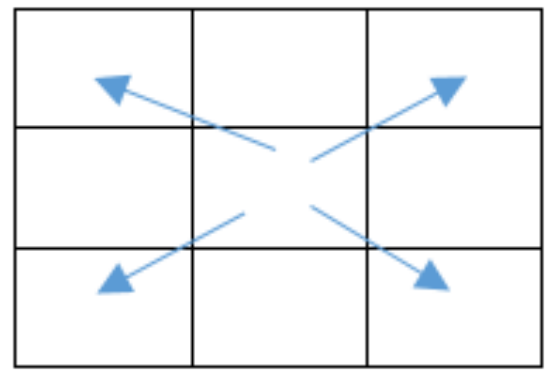

Gambar 2. Bishop Contiguity

3. Queen Contiguity: ini merupakan perpaduan dari Rook dan Bishop Contiguity sehingga akan memiliki 8 tetangga. Ketetanggaan Queen Contiguity dapat dilihat pada Gambar 3.

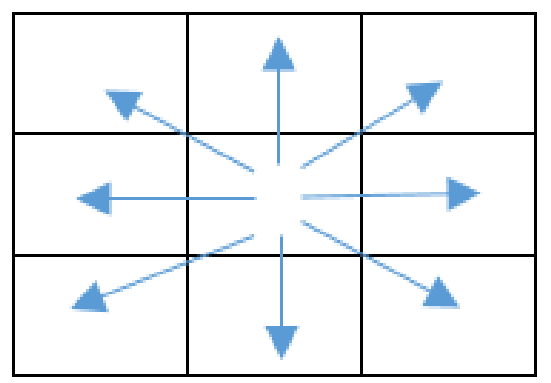

Gambar 3. Queen Contiguity

Dimisalkan $w$ dengan $w_{i j}$ elemen matriks tetangga spasial. Kemudian dilakukan standarisasi dengan membagi setiap elemen pada satu baris dengan jumlah elemen di dalam baris tersebut sehingga suatu matriks $w$ memiliki bobot spasial dengan elemen $w_{i j}$ seperti berikut ini,

$$
w_{i j}^{\prime}=\frac{w_{i j}}{\sum_{j} w_{i j}}
$$

Pembobot $w_{i j}$ yang merupakan berat spasial matriks mempunyai aturan bernilai 1 apabila letak antara lokasi i dan lokasi j saling berdekatan, sedangkan bernilai 0 apabila letak antara lokasi $i$ dan lokasi $j$ saling berjauhan.

\section{E. Autokorelasi Spasial}

Korelasi antara variabel dengan dirinya sendiri berdasarkan ruang atau dapat juga diartikan suatu ukuran kemiripan dari objek di dalam suatu ruang (jarak, waktu dan wilayah) [9]. Lebih lanjut Lembo menjelaskan adanya autokorelasi spasial mengindikasikan bahwa nilai atribut pada wilayah tertentu terkait oleh nilai atribut tersebut pada wilayah lain yang letaknya berdekatan atau bertetangga [9].

Autokerelasi spasial dapat di analisis dari dua perspektif yang berbeda yaitu analisis secara global dan secara lokal. Singkatnya Statistik global menjawab pertanyaan "Apakah ada pola spasial ?", dan statistik lokal menjawab pertanyaan "Dimana ada pola spasial ?" [10]. Beberapa indikator yang akan digunakan dalam menentukan autokorelasi spasial global mencakup metode Getis Ord General G dan Moran's I dalam penelitian ini hanya menggunakan Getis Ord General G dan dalam autokorelasi spasial lokal yaitu GetisOrd Gi*.

\section{F. Getis-Ord General G}

Getis-Ord General G merupakan alat uji statistik untuk melihat keterkaitan antar kota dalam hal pengelompokan, dimana melihat apakah daerah yang berdekatan saling berkelompok, pola pengelompokan yang dilihat adalah pengelompokan nilai-nilai tinggi/rendah dari suatu daerah terhadap tetangga terdekatnya. Persamaan Statistik General $\mathrm{G}$ adalah sebagai berikut [11],

$$
G=\frac{\sum_{i=1}^{n} \sum_{j=1}^{n} w_{i, j} x_{i} x_{j}}{\sum_{i=1}^{n} \sum_{j=1}^{n} x_{i} x_{j}}, \forall j \neq i
$$

Berdasarkan persamaan (6), G adalah nilai indeks GetisOrd General $\mathrm{G}, x_{i}$ dan $x_{j}$ adalah nilai atribut untuk fitur $i$ dan $j$, dan $w_{i, j}$ adalah elemen matriks bobot spasial antara fitur $i$ dan $j$.Untuk menghitung nilai $z_{G}$ maka digunakan persamaan berikut

$$
z_{G}=\frac{G-E[G]}{\sqrt{V[G]}}
$$

dimana, E[G] merupakan ekspektasi dari nilai indeks GetisOrd General $\mathrm{G}$ dan $V[G]$ merupakan variansi. Untuk menentukan nilai ekspektasi dan variansi digunakan persamaan (8) dan (9)

$$
E[G]=\frac{\sum_{i=1}^{n} \sum_{j=1}^{n} w_{i, j}}{n(n-1)}, \forall j \neq i
$$

$$
V[G]=E\left[G^{2}\right]-E[G]^{2}
$$

Berikut ini adalah perhitungan tambahan untuk menghitung nilai $\mathrm{E}\left[\mathrm{G}^{2}\right]$,

$$
E\left[G^{2}\right]=\frac{A+B}{C}
$$

dimana,

$$
\begin{aligned}
& A=D_{0}\left(\sum_{i=1}^{n} x_{i}^{2}\right)^{2}+D_{1} \sum_{i=1}^{n} x_{i}^{4}+D_{2}\left(\sum_{i=1}^{n} x_{i}\right)^{2} \sum_{i=1}^{n} x_{i}^{2} \\
& B=D_{3} \sum_{i=1}^{n} x_{i} \sum_{i=1}^{n} x_{i}^{3}+D_{4}\left(\sum_{i=1}^{n} x_{i}\right)^{4} \\
& C=\left[\left(\sum_{i=1}^{n} x_{i}\right)^{2}-\sum_{i=1}^{n} x_{i}^{2}\right]^{2} n(n-1)(n-2)(n-3) \\
& \text { dengan, } \\
& D_{0}=\left(n^{2}-3 n+3\right) S_{1}-n S_{2}+3 W^{2}
\end{aligned}
$$


$D_{1}=-\left[\left(n^{2}-n\right) S_{1}-2 n S_{2}+6 W^{2}\right]$

$D_{2}=-\left[2 n S_{1}-(n+3) S_{2}+6 W^{2}\right]$

$D_{3}=4(n-1) S_{1}-2(n+1) S_{2}+8 W^{2}$

$D_{4}=S_{1}-S_{2}+W^{2}$

$W=\left(\sum_{i=1}^{n} \sum_{j=1, i \neq j}^{n} w_{i, j}\right)$

$S_{1}=\left(\frac{1}{2}\right) \sum_{i=1}^{n} \sum_{j=1, i \neq j}^{n}\left(w_{i, j}+w_{j, i}\right)^{2}$

$S_{2}=\sum_{i=1}^{n}\left(\sum_{j=1, i \neq j}^{n} w_{i, j}+\sum_{j=1}^{n} w_{j, i}\right)^{2}$

Uji hipotesis untuk Getis-Ord General G adalah $\mathrm{H}_{0}$ : Tidak ada pengelompokan spasial dari nilai-nilai yang berdekatan,

$\mathrm{H}_{1}$ : Ada pengelompokan spasial dari nilai-nilai yang berdekatan.

Tingkat signifikansi yang digunakan adalah $\alpha=0,05 . \mathrm{H}_{0}$ diterima jika nilai- $p>0,05$ yang berarti tidak terdapat pengelompokan spasial atau keterkaitan antara satu wilayah dengan wilayah yang lain atau $\mathrm{H}_{0}$ ditolak jika nilai- $p \leqslant$ 0,05 yang berarti terdapat pengelompokan spasial atau keterkaitan antara satu wilayah dengan wilayah lain yang berdekatan.

\section{G. Getis-Ord Gi*}

Getis dalam Sulistyo [12] menjelaskan bahwa statistik $\mathrm{Gi}^{*}$ merupakan indikator pengelompokan yang mengukur konsentrasi dari variabel atribut $X$ di seluruh wilayah i yang terdistribusi secara spasial. Getis Ord Gi* menjelaskan secara lokal apakah terdapat pengelompokan spasial dari suatu daerah dengan daerah-daerah yang bertetangga terdekat dengannya pada periode waktu tertentu.

Statistik lokal Getis-Ord [13] diberikan pada persamaan berikut,

$$
G_{i}^{*}=\frac{\sum_{j=1}^{n} w_{i, j} x_{j}-\bar{X} \sum_{j=1}^{n} w_{i, j}}{S \sqrt{\frac{\left[n \sum_{j=1}^{n} w_{i, j}^{2}-\left(\sum_{j=1}^{n} w_{i, j}\right)^{2}\right]}{n-1}}}
$$

dimana $x_{j}$ adalah nilai atribut untuk fitur $j, w_{i, j}$ adalah berat spasial antara fitur $i$ dan $j, n$ sama dengan banyaknya fitur dan :

$$
\begin{aligned}
\bar{X} & =\frac{\sum_{j=1}^{n} x_{j}}{n} \\
S & =\sqrt{\frac{\sum_{j=1}^{n} x_{j}^{2}}{n}-(\bar{X})^{2}}
\end{aligned}
$$

$G i^{*}$ adalah nilai $z$ sehingga tidak diperlukan perhitungan lebih lanjut.

Pengujian autokorelasi spasial dengan menggunakan metode Getis-Ord Gi* dilakukan dengan hipotesis berikut : $\mathrm{H}_{0}$ : Tidak terdapat pengelompokan spasial dari satu nilai terhadap nilai-nilai tetangganya,

$\mathrm{H}_{1}$ : Terdapat pengelompokan spasial dari satu nilai terhadap nilai-nilai tetangganya.

Tingkat signifikansi yang digunakan adalah $\alpha=0,05 . \mathrm{H}_{0}$ diterima jika nilai- $p>0,05$ yang berarti tidak terdapat pengelompokan spasial atau keterkaitan antara satu wilayah dengan wilayah yang lain atau $\mathrm{H}_{0}$ ditolak jika nilai- $p \leqslant$ 0,05 yang berarti terdapat pengelompokan spasial atau keterkaitan antara satu wilayah dengan wilayah lain yang berdekatan.

\section{H. Metode Bootstrap}

Metode Bootstrap digunakan dengan harapan dapat memperoleh hasil perhitungan yang lebih akurat. Metode Boostrap merupakan metode berbasis resampling atau mengambil sampel terhadap sampel awal satu per satu dengan pengembalian, dan prosedur tersebut diulang sebanyak bilangan besar [14] .

Misal terdapat sampel awal $X_{1}, X_{2}, \ldots, X_{n}$. dibuat sampel baru yaitu $\left(X_{1}^{*}, X_{2}^{*}, \ldots, X_{n}^{*}\right)$ dengan cara membangkitkan sampel dengan rata-rata dan simpangan baku yang diperoleh dari sample awal, sampel awal dalam penelitian ini digunakan untuk menghitung statistik Indeks Getis-Ord General $\mathrm{G}$ dan Getis-Ord Gi*.

$$
T^{*}\left(X_{1}^{*}, X_{2}^{*}, \ldots, X_{n}^{*}\right)
$$

Prosedur diulang sebanyak bilangan besar (B) kali, sehingga diperoleh,

$$
T_{1}^{*}, T_{2}^{*}, \ldots, T_{B}^{*}
$$

Nilai- $p$ ditentukan dengan,

$$
\text { nilai }-p=\frac{\#\left(T_{i}^{*}>T_{\text {awal }}\right)}{B}
$$

dengan, $i=1,2, \ldots, B$ dan $T_{a w a l}=$ nilai statistik uji berdasarkan sampel awalnya.

Pengujian autokorelasi spasial dengan menggunakan metode Bootstrap dilakukan dengan hipotesis berikut :

$\mathrm{H}_{0}$ : Tidak terdapat autokorelasi atau pengelompokan spasial, $\mathrm{H}_{1}$ : Terdapat autokorelasi atau pengelompokan spasial.

Tingkat signifikansi yang digunakan adalah $\alpha=0,05 . \mathrm{H}_{0}$ diterima jika nilai- $p>0,05$ yang berarti tidak terdapat autokorelasi atau pengelompokan spasial atau keterkaitan antara satu wilayah dengan wilayah yang lain atau $\mathrm{H}_{0}$ ditolak jika nilai- $p \leqslant 0,05$ yang berarti terdapat autokorelasi atau pengelompokan spasial atau keterkaitan antara satu wilayah dengan wilayah lain yang berdekatan.

\section{METODE PENELITIAN}

\section{A. Data}

Data yang digunakan pada analisis ini adalah data sekunder yaitu data inflasi tahun ke tahun (yoy) pada kotakota inflasi di Pulau Sumatra dari Oktober 2009 sampai September 2019 yang diperoleh dari Badan Pusat Statistik. Terdapat 16 kota inflasi yang akan dianalisis antara lain Banda Aceh, Lhokseumawe, Sibolga, Pematang Siantar, Medan, Padang Sidimpuan, Padang, Pekanbaru, Dumai, Jambi, Palembang, Bengkulu, Bandar Lampung, Pangkal Pinang, Batam dan Tanjung Pinang. Data ini diasumsikan berdistribusi normal. Tabel I menunjukkan sample dari data yang akan digunakan dalam penelitian ini. 
TABEL I

DATA INFLASI KOTA-KOTA DI PULAU SUMATRA PADA OKTOBER - DESEMBER 2009

\begin{tabular}{|c|l|c|c|c|c|c|c|}
\hline \multirow{2}{*}{ No. } & \multirow{2}{*}{ KOTA } & \multicolumn{3}{|c|}{ 2009 } & \multicolumn{3}{c|}{ 2010 } \\
\cline { 2 - 8 } & & OKT & NOV & DES & JAN & FEB & MAR \\
\hline 1 & Banda Aceh & 5.03 & 4.84 & 3.5 & 4.37 & 4.49 & 3.6 \\
\hline 2 & Lhokseumawe & 5.2 & 4.12 & 3.96 & 5.16 & 3.99 & 4.44 \\
\hline 3 & Sibolga & 5.01 & 3.7 & 1.59 & 3.57 & 3.24 & 3.36 \\
\hline 4 & Pematang Siantar & 4.46 & 4.03 & 2.72 & 3.36 & 3.21 & 4 \\
\hline 5 & Medan & 3.43 & 2.46 & 2.69 & 4.39 & 5.1 & 4.65 \\
\hline 6 & Padangsidimpuan & 3.14 & 2.75 & 1.87 & 3.39 & 2.72 & 2.29 \\
\hline 7 & Padang & 4.36 & 2.94 & 2.05 & 3.75 & 3.23 & 3.05 \\
\hline 8 & Pekanbaru & 2.15 & 2.02 & 1.94 & 2.07 & 2.14 & 2.26 \\
\hline 9 & Dumai & 1.6 & 1.4 & 0.8 & 1.32 & 1.5 & 1.81 \\
\hline 10 & Jambi & 2.99 & 2.71 & 2.49 & 4.06 & 3 & 3.79 \\
\hline 11 & Palembang & 1.54 & 2.01 & 1.85 & 2.77 & 2.67 & 2.5 \\
\hline 12 & Bengkulu & 3.47 & 3.02 & 2.88 & 4.77 & 4.46 & 4.18 \\
\hline 13 & Bandar Lampung & 4.3 & 4.48 & 4.18 & 3.68 & 4.56 & 3.39 \\
\hline 14 & Pangkal Pinang & 1.69 & 1.87 & 2.17 & 2.87 & 4.13 & 4.38 \\
\hline 15 & Batam & 2.69 & 1.87 & 1.88 & 3.16 & 2.76 & 2.97 \\
\hline 16 & Tanjung Pinang & 3.07 & 1.25 & 1.43 & 0.68 & 1.04 & 1.92 \\
\hline
\end{tabular}

\section{B. Pengolahan Data}

Pengolahan data dalam penelitian ini menggunakan program R. Langkah-langkah dalam pengolahan data sebagai berikut:

1. Melakukan analisis statistik deskriptif

2. Melakukan Uji Mann Withney

3. Membuat matriks bobot dengan Queen Contiguity, khusus kota yang tidak berbatasan langsung atau berbatasan laut dicari dengan jarak terdekat kota tersebut ke kota lain berdasarkan peta wilayah.

4. Menstandardisasikan matriks bobot.

5. Melakukan perhitungan dan uji statistik Indeks Getis-Ord General.

6. Melakukan perhitungan dan Uji Statistik indeks Getis-Ord Gi*

7. Uji autokorelasi spasial menggunakan Metode Bootstrap pada data dan kemudian melakukan perhitungan dan uji Getis-Ord General $G$ dan Getis-Ord Gi*.

\section{HASIL DAN PEMBAHASAN}

\section{A. Statistik Deskriptif}

Tabel II menunjukan statistik deskriptif dari data yang digunakan pada periode Oktober 2009 sampai dengan September 2019. Dari tabel II juga diketahui rata-rata tertinggi inflasi di Pulau Sumatra pada periode waktu tersebut adalah rata-rata inflasi di kota Pangkal Pinang dengan rata-rata inflasi sebesar $5.82 \%$ dan rata-rata inflasi terendah berada di Banda Aceh. Namun jika dilihat dari nilai inflasi pada rentang waktu Oktober 2009 sampai dengan September 2019, inflasi tertinggi yang pernah terjadi di Pulau Sumatra tepatnya pada 16 kota inflasi ini adalah inflasi yang terjadi di Pematang Siantar yaitu sebesar $12.58 \%$ dengan standar deviasi 2.30 dan inflasi terendah adalah sebesar $0.06 \%$ di kota Banda Aceh dengan standar deviasi 1.63 .

TABEL III

STATISTIK DESKRIPTIF INFLASI DI PULAU SUMATRA PADA OKTIBER 2009 SAMPAI SEPTEMBER 2019

\begin{tabular}{|l|l|l|l|l|}
\hline \multicolumn{1}{|c|}{ Nama Kota } & Mean & Min & Max & SD \\
\hline Banda Aceh & 3.63 & 0.06 & 7.83 & 1.63 \\
\hline Lhokseumawe & 4.41 & 0.22 & 9.2 & 1.88 \\
\hline Sibolga & 5.57 & 0.78 & 12.45 & 2.25 \\
\hline Pematang Siantar & 5.40 & 1.61 & 12.58 & 2.30 \\
\hline Medan & 5.17 & 0.5 & 10.7 & 2.14 \\
\hline Padangsidimpuan & 4.51 & 1.66 & 8.89 & 1.68 \\
\hline Padang & 5.24 & 0.82 & 11.9 & 2.58 \\
\hline Pekanbaru & 4.81 & 1.3 & 8.87 & 1.88 \\
\hline Dumai & 4.63 & 0.75 & 10.95 & 2.22 \\
\hline Jambi & 4.79 & 1.03 & 10.52 & 2.18 \\
\hline Palembang & 4.17 & 0.54 & 8.38 & 1.63 \\
\hline Bengkulu & 5.56 & 1.41 & 10.85 & 2.34 \\
\hline Bandar Lampung & 5.14 & 0.77 & 10.99 & 2.19 \\
\hline
\end{tabular}




\begin{tabular}{|l|l|l|l|l|}
\hline \multicolumn{1}{|c|}{ Nama Kota } & Mean & Min & Max & SD \\
\hline Pangkal Pinang & 5.82 & 1.3 & 12.06 & 2.42 \\
\hline Batam & 4.61 & 0.61 & 9.2 & 1.77 \\
\hline Tanjung Pinang & 4.30 & 0.26 & 10.84 & 2.27 \\
\hline
\end{tabular}

\section{B. Uji Mann-Whitney}

Dari Tabel III dapat dilihat bahwa kota-kota dengan nilai $\left|Z_{\text {hitung }}\right|>1.96$ adalah kota Lhokseumawe, Sibolga, Pematang Siantar, Medan, Padangsidimpuan, Padang, Pekanbaru, Dumai, Jambi, Bengkulu, Bandar Lampung, Pangkal Pinang, dan Tanjung Pinang. Sehingga dapat diputuskan bahwa H0 ditolak, maka terdapat perbedaan laju inflasi tahun ke tahun di kota-kota tersebut pada periode 2009-2014 dan periode 2014-2019. Sedangkan pada Kota Banda Aceh, Palembang dan Batam tidak terdapat perbedaan laju inflasi pada periode 2009-2014 dan periode 2014-2019.

TABEL III

NILAI Z DAN NILAI P UJI MANN-WHITNEY

\begin{tabular}{|l|l|l|}
\hline \multicolumn{1}{|c|}{ Kota } & \multicolumn{1}{c|}{ Nilai Z } & \multicolumn{1}{c|}{ Nilai $\boldsymbol{p}$} \\
\hline Banda Aceh & -0.562 & 0.5743750 \\
\hline Lhokseumawe & -2.834 & 0.0045920 \\
\hline Sibolga & -2.391 & 0.0168119 \\
\hline Pematang Siantar & -5.404 & 0.0000001 \\
\hline Medan & -2.157 & 0.0309885 \\
\hline Padangsidimpuan & -3.858 & 0.0001144 \\
\hline Padang & -3.664 & 0.0002487 \\
\hline Pekanbaru & -2.832 & 0.0046304 \\
\hline Dumai & -2.155 & 0.0311920 \\
\hline Jambi & -4.789 & 0.0000017 \\
\hline Palembang & -1.262 & 0.2068315 \\
\hline Bengkulu & -2.847 & 0.0044072 \\
\hline Bandar Lampung & -4.480 & 0.0000075 \\
\hline Pangkal Pinang & -3.538 & 0.0004037 \\
\hline Batam & -0.417 & 0.6764775 \\
\hline Tanjung Pinang & -3.333 & 0.0008593 \\
\hline
\end{tabular}

\section{Matriks Bobot Spasial}

Berdasarkan dua sumber informasi lokasi yang dapat diketahui seperti pada Bab II yaitu ketetanggaan dan jarak maka untuk membangun matriks bobot objek spasial dari 16 kota inflasi di Pulau Sumatra dilakukan dengan terlebih dahulu menentukan ketatanggaannya, 16 kota inflasi di Pulau Sumatra tidak semua bertetangga langsung sehingga dalam penentuan ketetanggaannya selain menggunakan matriks bobot dengan Queen Contiguity, khusus kota yang tidak berbatasan langsung sepeti berbatasan laut dan berbatasan dengan kota lain yang bukan merupakan kota inflasi maka dicari dengan jarak terdekat provinsi tersebut ke provinsi lain dengan peta Pulau Sumatra pada Gambar 4.

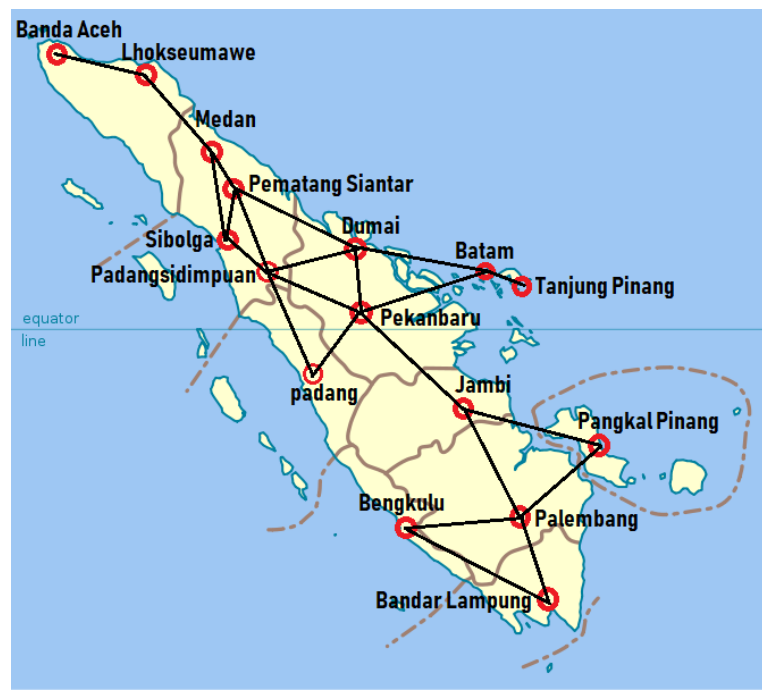

Gambar 4. Peta Pulau Sumatra dengan Informasi Ketetanggaan

Berdasarkan informasi yang terdapat pada Gambar 4 maka dibuat matriks ketetanggaan seperti yang terdapat pada Gambar 5 dengan asumsi kota yang bertetangaan bernilai 1 dan lainnya bernilai 0 .

\begin{tabular}{|c|c|c|c|c|c|c|c|c|c|c|c|c|c|c|c|c|}
\hline & 1 & 2 & 3 & 4 & 5 & 6 & 7 & 8 & 9 & 10 & 11 & 12 & 13 & 14 & 15 & 16 \\
\hline 1 & 0 & 1 & 0 & 0 & 0 & 0 & 0 & 0 & 0 & 0 & 0 & 0 & 0 & 0 & 0 & 0 \\
\hline 2 & 1 & 0 & 0 & 0 & 1 & 0 & 0 & 0 & 0 & 0 & 0 & 0 & 0 & 0 & 0 & 0 \\
\hline 3 & 0 & 0 & 0 & 1 & 1 & 1 & 0 & 0 & 0 & 0 & 0 & 0 & 0 & 0 & 0 & 0 \\
\hline 4 & 0 & 0 & 1 & 0 & 1 & 1 & 0 & 0 & 1 & 0 & 0 & 0 & 0 & 0 & 0 & 0 \\
\hline 5 & 0 & 1 & 1 & 1 & 0 & 0 & 0 & 0 & 0 & 0 & 0 & 0 & 0 & 0 & 0 & 0 \\
\hline 6 & 0 & 0 & 1 & 1 & 0 & 0 & 1 & 1 & 1 & 0 & 0 & 0 & 0 & 0 & 0 & 0 \\
\hline 7 & 0 & 0 & 0 & 0 & 0 & 1 & 0 & 1 & 0 & 0 & 0 & 0 & 0 & 0 & 0 & 0 \\
\hline 8 & 0 & 0 & 0 & 0 & 0 & 1 & 1 & 0 & 1 & 1 & 0 & 0 & 0 & 0 & 1 & 0 \\
\hline 9 & 0 & 0 & 0 & 1 & 0 & 1 & 0 & 1 & 0 & 0 & 0 & 0 & 0 & 0 & 1 & 0 \\
\hline 10 & 0 & 0 & 0 & 0 & 0 & 0 & 0 & 1 & 0 & 0 & 1 & 0 & 0 & 1 & 0 & 0 \\
\hline 11 & 0 & 0 & 0 & 0 & 0 & 0 & 0 & 0 & 0 & 1 & 0 & 1 & 1 & 1 & 0 & 0 \\
\hline 12 & 0 & 0 & 0 & 0 & 0 & 0 & 0 & 0 & 0 & 0 & 1 & 0 & 1 & 0 & 0 & 0 \\
\hline 13 & 0 & 0 & 0 & 0 & 0 & 0 & 0 & 0 & 0 & 0 & 1 & 1 & 0 & 0 & 0 & 0 \\
\hline 14 & 0 & 0 & 0 & 0 & 0 & 0 & 0 & 0 & 0 & 1 & 1 & 0 & 0 & 0 & 0 & 0 \\
\hline 15 & 0 & 0 & 0 & 0 & 0 & 0 & 0 & 1 & 1 & 0 & 0 & 0 & 0 & 0 & 0 & 1 \\
\hline 16 & 0 & 0 & 0 & 0 & 0 & 0 & 0 & 0 & 0 & 0 & 0 & 0 & 0 & 0 & 1 & 0 \\
\hline
\end{tabular}

Gambar 5. Matriks Bobot

Matriks bobot pada Gambar 5 merupakan matriks bobot tak terstadarisasi sehingga matriks tersebut perlu distandarisasi dan hasil standarisasi dari matriks tersebut adalah matriks yang terdapat pada Gambar 6 berikut.

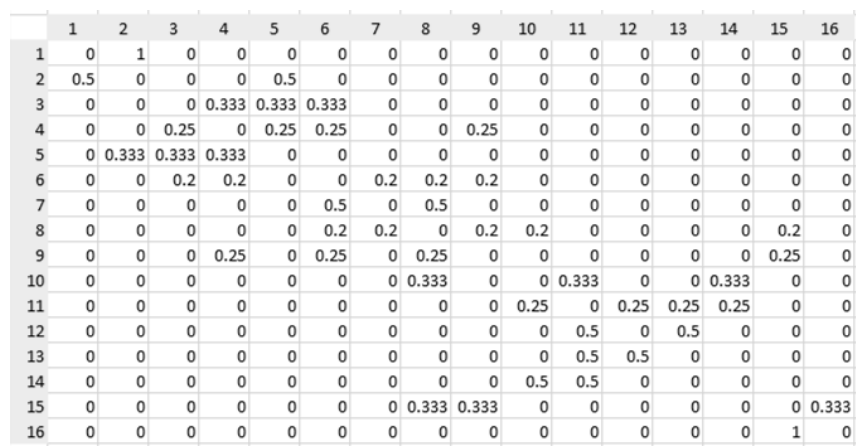

Gambar 6. Matriks Bobot Terstandarisasi 
Matriks yang sudah terstandarisasi yang selanjutnya akan digunakan dalam perhitungan Indeks Getis-Ord General G, Getis-Ord Gi* dan Moran's I, dimana matriks tersebut disimbolkan sebagai matrik $W$.

\section{Uji Statistik Indeks Getis-Ord General G}

Hasil perhitungan diketahui bahwa hanya pada bulan Februari 2014 nilai $|Z(G)|>Z_{\alpha / 2}$ dan nilai- $p<\alpha=0.05$ sehingga dapat disimpulkan bahwa pada tingkat signifikansi $\alpha=0.05$ dinyatakan $\mathrm{H}_{0}$ ditolak yang berarti pada bulan Februari 2014 terdapat pengelompokan spasial antar kotakota yang berbatasan atau berdekatan berkaitan dengan laju inflasi di Pulau Sumatra. Tabel IV berikut menunjukan nilai $\mathrm{Z}$ dan nilai- $p$ pada Februari 2014 dan beberapa waktu lainnya yang tidak memenuhi syarat untuk menolak hipotesis awal.
TABEL IV

NILAI Z DAN NILAI P UJI STATISTIK INDEKS GETIS-ORD GENERAL G

\begin{tabular}{|c|c|c|c|c|c|c|}
\hline $\begin{array}{c}\text { Bulan/ } \\
\text { Tahun }\end{array}$ & G & $\mathbf{E}(\mathbf{G})$ & $\mathbf{V}(\mathbf{G})$ & $\mathbf{Z}(\mathbf{G})$ & $\begin{array}{c}\text { Nilai- } \\
\boldsymbol{p}\end{array}$ & Hasil \\
\hline Feb-14 & 0.064 & 0.067 & $156 \times 10^{-7}$ & -2.181 & 0.029 & Ada \\
\hline
\end{tabular}

Gambar 5 menunjukkan hasil perhitungan nilai indeks Getis Ord General G, Gambar 6 menunjukkan hasil perhitungan nilai $Z(G)$ dengan nilai yang bertanda merah merupakan nilai yang memenuhi syarat untuk menolak $\mathrm{H}_{0}$ dan hasil perhitungaan nilai- $p$ dengan program $\mathrm{R}$ pada Gambar 7.

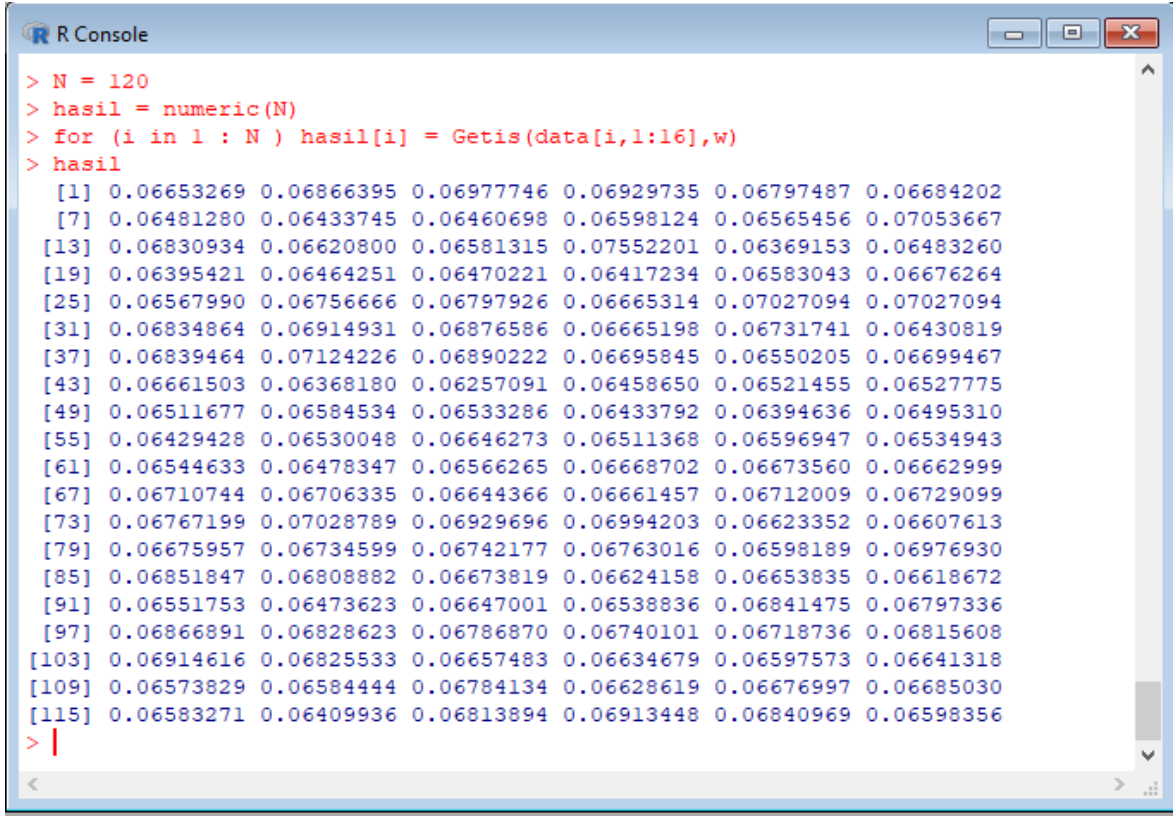

Gambar 5. Hasil perhitungan nilai indeks Getis Ord General G dengan program R 


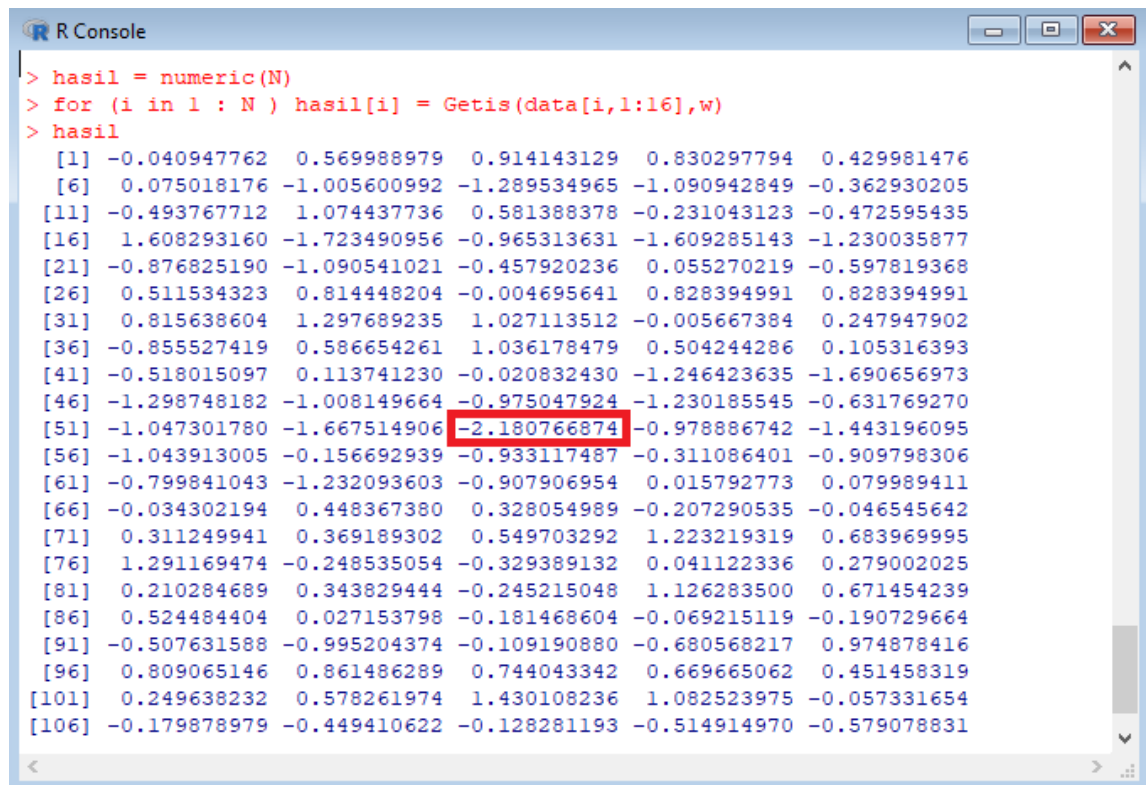

Gambar 6. Hasil perhitungan nilai Z Getis Ord General G dengan program R

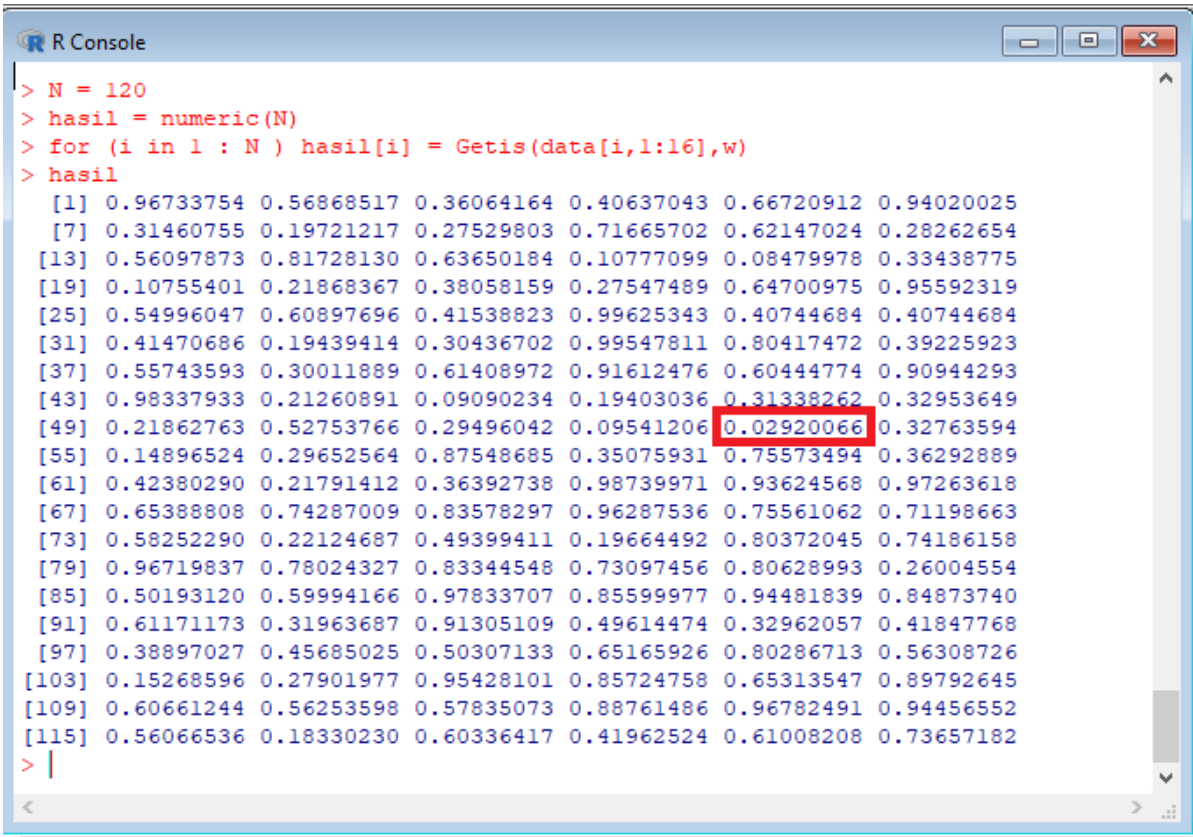

Gambar 7. Hasil perhitungan nilai Z Getis Ord General G dengan program $R$

TABEL $V$

NILAI Z DAN NILAI P UJI STATISTIK INDEKS GETIS-ORD GI*

\begin{tabular}{|c|c|c|c|c|c|c|c|c|c|c|}
\hline \multirow[b]{2}{*}{ Kota } & \multicolumn{2}{|c|}{ Nov-12 } & \multicolumn{2}{|c|}{ Jan-13 } & \multicolumn{2}{|c|}{ Agu-13 } & \multicolumn{2}{|c|}{ Jul-15 } & \multicolumn{2}{|c|}{ Apr-19 } \\
\hline & $\mathrm{Gi}^{*}$ & Nilai-p & $\mathrm{Gi}^{*}$ & Nilai-p & $\mathrm{Gi}^{*}$ & Nilai-p & $\mathrm{Gi}^{*}$ & Nilai-p & $\mathrm{Gi}^{*}$ & $\begin{array}{c}\text { Nilai- } \\
\mathrm{p}\end{array}$ \\
\hline Banda Aceh & -2.02 & 0.04 & -2.17 & 0.03 & -1.99 & 0.05 & -1.97 & 0.05 & 0.76 & 0.45 \\
\hline Lhokseumawe & -0.82 & 0.42 & -1.21 & 0.23 & -0.36 & 0.72 & -0.66 & 0.51 & 0.10 & 0.92 \\
\hline Sibolga & 0.39 & 0.69 & 0.00 & 1.00 & 0.51 & 0.61 & -0.19 & 0.85 & -0.12 & 0.91 \\
\hline Pematang Siantar & 0.31 & 0.76 & 0.19 & 0.85 & 0.09 & 0.93 & 0.11 & 0.91 & -0.41 & 0.68 \\
\hline Medan & -0.23 & 0.82 & -0.50 & 0.62 & -0.34 & 0.74 & -0.44 & 0.66 & 0.64 & 0.52 \\
\hline
\end{tabular}




\begin{tabular}{|c|c|c|c|c|c|c|c|c|c|c|}
\hline \multirow[b]{2}{*}{ Kota } & \multicolumn{2}{|c|}{ Nov-12 } & \multicolumn{2}{|c|}{ Jan-13 } & \multicolumn{2}{|c|}{ Agu-13 } & \multicolumn{2}{|c|}{ Jul-15 } & \multicolumn{2}{|c|}{ Apr-19 } \\
\hline & $\mathrm{Gi}^{*}$ & Nilai-p & $\mathrm{Gi}^{*}$ & Nilai-p & $\mathrm{Gi}^{*}$ & Nilai-p & $\mathrm{Gi}^{*}$ & Nilai-p & $\mathrm{Gi}^{*}$ & $\begin{array}{c}\text { Nilai- } \\
\mathrm{p}\end{array}$ \\
\hline Padangsidimpuan & 0.36 & 0.72 & 0.41 & 0.68 & 0.38 & 0.70 & 0.32 & 0.75 & -0.33 & 0.74 \\
\hline Padang & 0.25 & 0.80 & 0.26 & 0.79 & -0.27 & 0.78 & -0.49 & 0.63 & -1.08 & 0.28 \\
\hline Pekanbaru & -0.02 & 0.98 & 0.20 & 0.84 & 0.15 & 0.88 & 0.22 & 0.83 & 0.09 & 0.93 \\
\hline Dumai & -0.02 & 0.98 & -0.13 & 0.90 & -0.20 & 0.84 & 0.04 & 0.97 & 0.15 & 0.88 \\
\hline Jambi & 0.58 & 0.56 & 0.23 & 0.82 & 0.02 & 0.98 & 0.00 & 1.00 & -0.91 & 0.37 \\
\hline Palembang & 0.85 & 0.39 & 0.79 & 0.43 & 0.54 & 0.59 & 0.31 & 0.75 & -0.34 & 0.73 \\
\hline Bengkulu & 0.01 & 0.99 & 0.12 & 0.91 & -0.26 & 0.79 & 0.62 & 0.54 & -0.38 & 0.70 \\
\hline Bandar Lampung & 0.09 & 0.93 & 0.19 & 0.85 & 0.16 & 0.88 & 0.45 & 0.66 & -0.78 & 0.44 \\
\hline Pangkal Pinang & 0.16 & 0.87 & 0.08 & 0.94 & 0.20 & 0.84 & -0.28 & 0.78 & -0.41 & 0.68 \\
\hline Batam & -0.03 & 0.98 & 0.37 & 0.71 & -0.17 & 0.87 & -0.23 & 0.82 & -0.73 & 0.47 \\
\hline Tanjung Pinang & -1.20 & 0.23 & -1.08 & 0.28 & -1.06 & 0.29 & 1.41 & 0.16 & 2.32 & 0.02 \\
\hline
\end{tabular}

\section{E. Uji Statistik Indeks Getis-Ord Gi*}

$\mathrm{H}_{0}$ diterima dengan taraf signifikansi $\left|Z\left(G i^{*}\right)\right|>Z_{\alpha / 2}$ dengan $Z_{\alpha / 2}$ adalah $Z_{0.025}=1.96$. Dari Tabel $\mathrm{V}$ dapat dilihat bahwa yang memenuhi syarat untuk menolak $\mathrm{H}_{0}$ adalah kota Banda Aceh pada November 2012 dengan nilai Z sebesar 2.02 dan nilai-p sebesar 0.04389, Januari 2013 dengan nilai Z sebesar -2.17 dan nilai- $p$ sebesar 0.02976, Agustus 2013 dengan nilai $Z$ sebesar -1.99 dan nilai- $p$ sebesar 0.04665 , dan Juli 2015 dengan nilai $Z$ sebesar -1.97 dan nilai- $p$ sebesar 0.04937, serta kota Tanjung Pinang pada April 2019 dengan nilai $\mathrm{Z}$ sebesar 2.32 dan nilai-p sebesar 0.02014. Sehingga di Kota Banda Aceh dan Kota Tanjung Pinang pada masing-masing waktu yang disebut menolak hipotesis awal yang berarti terdapat pengelompokan spasial antar kota tersebut dengan kota-kota yang bertentangga dengannya.

Berdasarkan ketetanggaan terdekat secara spasial, kota yang diasumsikan sebagai tetangga terdekat kota Banda Aceh adalah Kota Lhokseumawe dan tetangga terdekat kota Tanjung Pinang adalah kota Batam. Z bernilai negatif pada masing-masing waktu di Kota Banda Aceh mengasumsikan bahwa di Kota Banda Aceh terdapat pengelompokan spasial nilai-nilai rendah dalam hal ini pengelompokan spasial nilai inflasi yang rendah dari Kota Banda Aceh dan tetangga terdekatnya yaitu kota Lhokseumawe dan Z bernilai positif pada April 2019 di kota Tanjung Pinang yang mengasumsikan bahwa terdapat pengelompokan nilai-nilai tinggi kota yang bertetangga terdekat dengan Kota Tanjung Pinang yaitu Kota Batam. Gambar 8 menunjukkan tampilan hasil perhitungan nilai indeks Getis Ord Gi* dengan menggunakan program $\mathrm{R}$.

\section{F. Penerapan Metode Bootstrap}

Dengan metode Bootstrap dilakukan resampling sehingga diperoleh data baru. Kemudian dilakukan uji autokorelasi pada data baru tersebut dengan metode yang sama yaitu dengan uji statistik Indeks Getis-Ord General G dan Getis-
Ord $\mathrm{Gi}^{*}$. Uji autokorelasi dan pengelompokan spasial menggunakan metode Boostrap dengan hipotesis,

$\mathrm{H}_{0}$ : Tidak terdapat autokorelasi/pengelompokan spasial,

$\mathrm{H}_{1}$ : Terdapat autokorelasi/pengelompokan spasial.

TABEL VI

NILAI-P BOOTSTRAP INDEKS GETIS-ORD GENERAL G

\begin{tabular}{|c|c|c|}
\hline \multirow{2}{*}{ Bulan/Tahun } & \multicolumn{2}{|c|}{ Getis-Ord General G } \\
\cline { 2 - 3 } & Nilai- $\boldsymbol{p}$ & Kesimpulan \\
\hline Feb-14 & 0.016 & Ada Cluster \\
\hline
\end{tabular}

Dengan tingkat signifikan $\alpha=0.05$. Kesimpulan untuk $\mathrm{H}_{0}$ adalah dengan melihat besarnya nilai- $p$, jika nilai- $p$ lebih besar dari 0.05 maka $\mathrm{H}_{0}$ diterima yang berarti bahwa tidak terdapat autokorelasi/pengelompokan spasial dan sebaliknya.

Berdasarkan metode Bootstrap dengan pengulangan $B=10.000$ kali maka di peroleh nilai- $p$ pada Tabel VI dimana nilai- $p$ untuk indeks Getis-Ord General $G$ yang kurang dari 0.05 hanya pada bulan Februari 2014 sehingga $\mathrm{H}_{0}$ ditolak yang berarti bahwa terdapat autokorelasi/pengelompokan spasial dan terdapat keterkaitan antara satu wilayah dengan wilayah lain yang berbatasan.

Tabel VII menunjukkan waktu dimana ada kota yang memenuhi syarat untuk menolak hipotesis awal yaitu kota Banda Aceh dan Kota Tanjung Pinang dimana terdapat pengelompokan spasial untuk kota Banda Aceh pada November 2012, Januari 2013, Agustus 2013, Februari 2014, April 2014 dan Juli 2015 serta terdapat pengelompokan spasial pada kota Tanjung Pinang pada November 2015. Sedangkan pada waktu lainnya dalam Oktober 2009 sampai dengan September 2019 tidak menunjukkan adanya kota yang berkelompok secara spasial dengan tetangga terdekatnya. Hal ini sejalan dengan hasil uji statistik indeks Getis-Ord Gi* menunjukkan bahwa terdapat pengelompokan spasial secara lokal terpatnya di Kota Banda Aceh dan Kota Tanjung Pinang. 


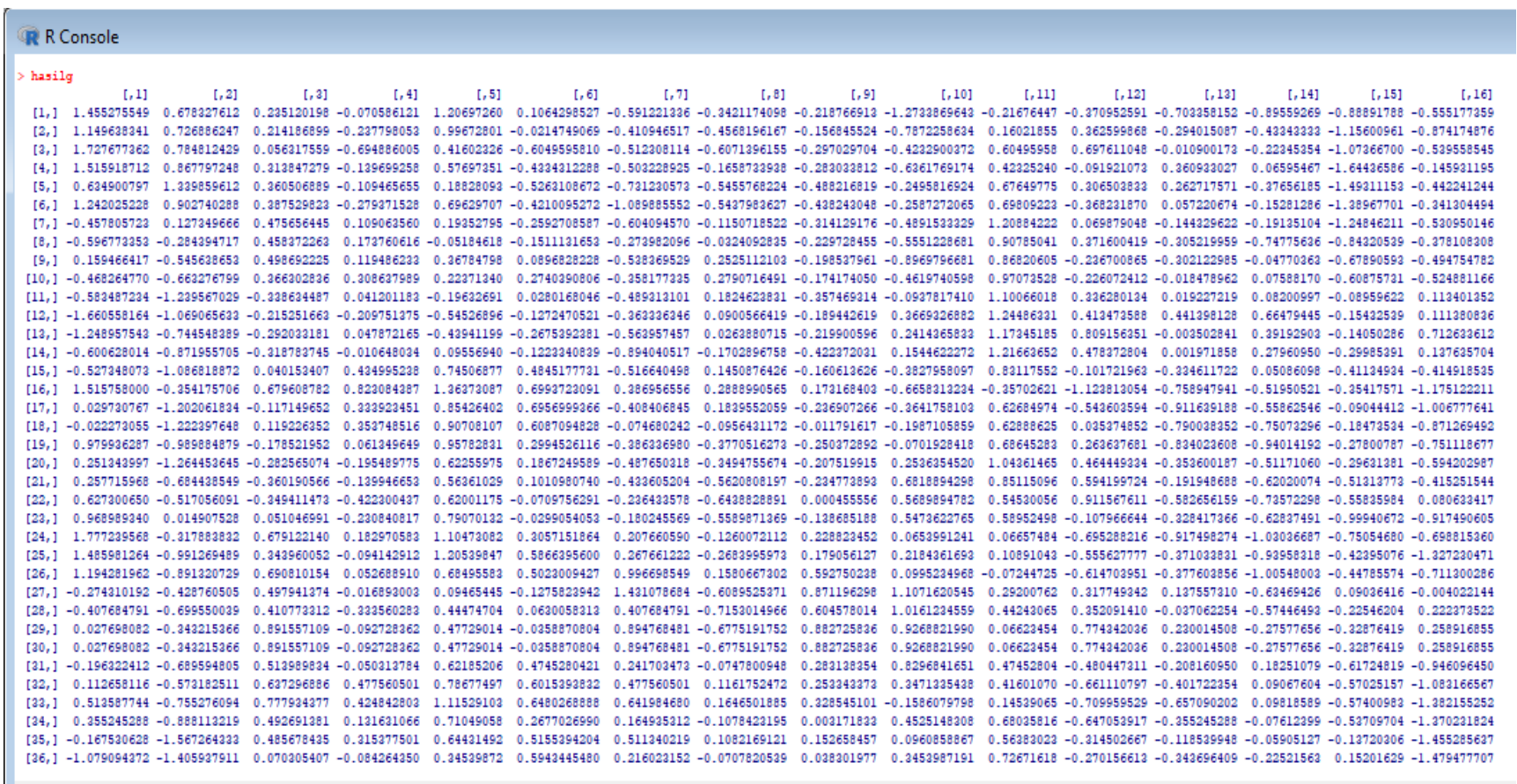

Gambar 8. Tampilan hasil perhitungan nilai Getis Ord Gi* dengan Program R

TABEL VII

NILAI NILAI-P BOOTSTRAP INDEKS GETIS-ORD GI*

\begin{tabular}{|l|c|c|c|c|c|c|c|c|}
\hline \multicolumn{1}{|c|}{ Kota } & Nov-12 & Jan-13 & Agu-13 & Feb-14 & Mar-14 & Apr-14 & Jul-15 & Nov-15 \\
\hline Banda Aceh & 0.044 & 0.045 & 0.030 & 0.040 & 0.034 & 0.027 & 0.031 & 0.560 \\
\hline Lhokseumawe & 0.307 & 0.173 & 0.748 & 0.992 & 0.975 & 0.919 & 0.515 & 0.846 \\
\hline Sibolga & 0.639 & 0.999 & 0.626 & 0.808 & 0.732 & 0.933 & 0.835 & 0.862 \\
\hline Pematang Siantar & 0.717 & 0.861 & 0.940 & 0.926 & 0.935 & 0.922 & 0.899 & 0.758 \\
\hline Medan & 0.806 & 0.634 & 0.729 & 0.765 & 0.716 & 0.642 & 0.651 & 0.736 \\
\hline Padangsidimpuan & 0.653 & 0.735 & 0.725 & 0.801 & 0.715 & 0.817 & 0.721 & 0.618 \\
\hline Padang & 0.779 & 0.820 & 0.809 & 0.724 & 0.980 & 0.834 & 0.613 & 0.410 \\
\hline Pekanbaru & 0.982 & 0.879 & 0.899 & 0.953 & 0.786 & 0.803 & 0.828 & 0.790 \\
\hline Dumai & 0.987 & 0.918 & 0.864 & 0.957 & 0.766 & 0.962 & 0.960 & 0.992 \\
\hline Jambi & 0.455 & 0.855 & 0.986 & 0.937 & 0.612 & 0.811 & 1.000 & 0.808 \\
\hline Palembang & 0.298 & 0.381 & 0.611 & 0.847 & 0.872 & 0.893 & 0.734 & 0.516 \\
\hline Bengkulu & 0.992 & 0.910 & 0.819 & 0.327 & 0.301 & 0.365 & 0.545 & 0.346 \\
\hline Bandar Lampung & 0.910 & 0.878 & 0.891 & 0.977 & 0.933 & 0.986 & 0.641 & 0.547 \\
\hline Pangkal Pinang & 0.868 & 0.938 & 0.838 & 0.607 & 0.747 & 0.944 & 0.778 & 0.924 \\
\hline Batam & 0.972 & 0.751 & 0.875 & 0.892 & 0.523 & 0.539 & 0.814 & 0.899 \\
\hline Tanjung Pinang & 0.216 & 0.195 & 0.274 & 0.839 & 0.758 & 0.971 & 0.153 & 0.046 \\
\hline
\end{tabular}




\section{KESIMPULAN}

Hasil analisis menunjukkan rata-rata inflasi tertinggi berada di Kota Pangkal Pinang sebesar 5.82 dan terendah berada di Kota Banda Aceh sebesar 3.63. Terdapat perbedaan median laju inflasi yang signifikan dari kota-kota inflasi di Pulau Sumatra kecuali di Kota Banda Aceh, Palembang dan Batam. Dengan taraf signifikansi $\alpha=5 \%$, diperoleh kesimpulan bahwa terdapat keterkaitan dalam pola pengelompokan spasial pada Februari 2014. Kota dengan pengelompokan nilai inflasi tinggi dengan tetangganya adalah Kota Pangkal Pinang dan pengelompokan nilai inflasi rendah adalah Kota Banda Aceh. Hal itu berarti bahwa antar satu daerah dengan daerah lainnya yang saling berdekatan memiliki kemiripan tingkat inflasi dalam hal tinggi rendahnya pada waktu tententu. Dengan kata lain, komoditas penyumbang inflasi antar daerah yang berdekatan saling berkaitan.

\section{DAFTAR PUSTAKA}

[1] Bank Indonesia. (2018) "Pengenalan inflasi". [Online]. Tersedia :https://www.bi.go.id/id/moneter/inflasi/pengenalan

[2] S. Syamsuddin and D. Karya, Makro Ekonomi, Jakarta: PT RajaGrafindo Persada, 2016.

[3] Badan Pusat Statistik (2019) "Pertumbuhan ekonomi Indonesia triwulan IV-2018". [Online]. Tersedia https://www.bps.go.id/pressrelease/2019/02/06/1619/ekonomiindonesia-2018-tumbuh-5-17-persen.html.

[4] A. Setiawan, "Perbandingan karakteristik inflasi kota-kota di
Indonesia bagian timur sebelum dan sesudah krisis moneter 1998,' d'CARTESIAN, vol 3, no. 1, pp. 9-16, Maret 2014.

[5] E. K. Nisa, "Identifikasi spatial pattern dan spatial autocorrelation pada indeks pembangunan manusia provinsi Papua Barat tahun 2012," Jurnal At-Taqaddum, vol 9, no. 2, pp. 202-226, Nov 2017.

[6] T. Wuryandari, A. Hoyyi, D. Kusumawardani, and D. Rahmawati, "Identifikasi autokorelasi spasial pada jumlah pengangguran di Jawa Tengah menggunakan indeks moran," MEDIA STATISTIKA, vol. 7 , no. 1, pp. 1-10, Juni 2014. https://doi.org/10.14710/medstat.7.1.1-10

[7] A. Setiawan, Analisis Data Statistik. Salatiga: Tisara Grafika, 2017.

[8] N. P. Yuriantari, M. N. Hayati, and S. Wahyuningsih, "Analisis autokorelasi spasialtitik panas di Kalimantan Timur menggunakan indeks moran dan local indicator of spatial autocorrelation (LISA)" Eksponensial, vol. 8, no. 1, pp. 63-70, 2017.

[9] A. Lutfi, M. K. Aidid, and Sudarmin, "Identifikasi autokorelasi spasial angka partisipasi sekolah di provinsi Sulawesi Selatan menggunakan indeks moran," Journal of Statistics and Its application on Teaching and Research, vol. 1, no. 2, pp. 1-8, 2019.

[10] M. Mathur, "Spatial autocorrelation analysis in plant population: an overview," J. Appl. Nat. Sci., vol. 7, no. 1, pp. 501-513, 2015.

[11] A. Luc, R. Sergio J, Eds., Perspectives on Spatial Data Analysis, seri Advances in Spatial Science. United States : Springer, 2010.

[12] W. Sulistyo et al., "Pemodelan spatial autocorrelation kondisi ketahanan dan kerentanan pangan di kabupaten Klaten," Prosiding SENTIKA, 2015, pp. 35-42.

[13] Esri, (2013) "How hot spot analysis: Getis-Ord Gi* (spatial statistics) works," [Online]. Tersedia: https://pro.arcgis.com/en/pro-app/toolreference/spatial-statistics/h-how-hot-spot-analysis-getis-ord-gispatial-stati.htm

[14] A. Setiawan, "Perbandingan koefisien variasi antara 2 sampel dengan metode bootstrap," d'CARTESIAN, vol. 1, no. 1, p. 18, 2012 doi: $10.35799 / \mathrm{dc} \cdot 1.1 .2012 .531$. 